\title{
Implementasi Decision Tree C4.5 Untuk Menentukan Status Berat Badan dan Kebutuhan Energi Pada Anak Usia 7-12 Tahun
}

\author{
Supangat \\ Program Studi Teknik Informatika \\ Universitas 17 Agustus 1945 \\ Surabaya \\ supangat@untag-sby.ac.id
}

\author{
Anis R. Amna \\ Program Studi Teknik Informatika \\ Universitas 17 Agustus 1945 \\ Surabaya \\ anis.r.amna@untag-sby.ac.id
}

\author{
Titasari Rahmawati \\ Program Studi Manajemen \\ Informatika \\ Institut Informatika Indonesia \\ tita@ikado.ac.id
}

\begin{abstract}
Abstrak - Decision Tree 4.5 merupakan salah satu algoritma klasifikasi yang banyak digunakan untuk memperoleh hasil klasifikasi non biner. Dibanding algoritma sejenis, Decision Tree 4.5 memiliki kelebihan pada kemampuan untuk mengelola data dalam berbagai format. Kelebihan inilah yang dicoba dimanfaatkan untuk memperoleh hasil klasifikasi kebutuhan nutrisi bagi anak usia sekolah dasar. Berdasarkan hasil pengujian menggunakan Decision Tree terhadap 360 siswa sekolah dasar berusia 7-12 tahun, diperoleh hasil bahwa $79,7 \%$ siswa memiliki berat badan normal, $12,5 \%$ siswa mengalami kekurangan berat badan, dan $\mathbf{7 , 8 \%}$ siswa mengalami kelebihan berat badan. Dari kondisi tersebut, pengujian lebih lanjut menggunakan Decision Tree menunjukkan bahwa faktor usia, berat badan, tinggi badan, BMR, dan BMI memiliki kontribusi pada penentuan kebutuhan energi pada anak, dan jenis kelamin mempengaruhi pada proses penentuan kebutuhan konsumsi karbohidrat, protein, lemak, dan serat.
\end{abstract}

Kata Kunci: Data Mining, Decision Tree C4.5, Klasifikasi, Status Gizi Pada Anak Usia 7-12 Tahun

\section{PENDAHULUAN}

Gizi memiliki peran penting untuk menciptakan Sumber Daya Manusia (SDM) yang sehat, cerdas, tangguh, serta produktif. Untuk itu, upaya peningkatan kualitas gizi seharusnya dimulai sejak usia dini. Walaupun demikian, tidak mengidentifikasi secara detil permasalahan yang menyebabkan kurangnya berat badan ideal pada anak usia 512 tahun. Akibatnya, sulit mengetahui penyebab kondisi fisik pada 3,4\% anak di Indonesia yang teridentifikasi sangat kurus dan 7,5\% yang mengalami kondisi fisik kurus [1].

Penelitian yang dilakukan oleh Andriani Elisa pada 64 siswa sekolah dasar diketahui bahwa status gizi pada anak dipengaruhi oleh tingkat pengetahuan ibu, tingkat pendidikan ibu, pendapatan keluarga, penyakit menular, serta tingkat konsumsi energi dan protein [2]. Penelitian lebih lanjut dilakukan oleh Lestari, Ernalia, \& Restuastuti, menggunakan 210 responden yang merupakan siswa sekolah dasar di Kabupaten Rokan Hilir. Hasil penelitian menunjukkan bahwa $23,8 \%$ siswa mengalami kondisi kekurangan gizi, dan $27,6 \%$ diantaranya kurang berat badan [3]. Senada dengan temuan sebelumnya, hasil penelitian yang dilakukan oleh Ira Widya Jahri dan Suyanto pada 350 siswa sekolah dasar di Siak Kecil Bengkalis menunjukkan bahwa $1,7 \%$ siswa mengalami malnutrisi, $12 \%$ diantaranya mengalami kekurangan berat badan [4].

Kebiasaan sarapan pagi antara pukul 07.00 hingga 08.00 selain mencegah terjadinya hipoglikemi juga berfungsi untuk memenuhi $15-30 \%$ kebutuhan gizi dalam sehari [5]. Walaupun demikian, sebagian besar masyarakat Indonesia tidak terbiasa melakukan sarapan pagi. Jikapun sebaliknya, penyediaan makanan pada saat sarapan masih kurang baik dan jumlah gizinya kurang seimbang [6].

Berdasarkan permasalahan tersebut, penelitian ini bertujuan untuk merancang sistem pendukung keputusan yang dapat memberikan rekomendasi menu sarapan sehat sesuai standar pemenuhan gizi seimbang menggunakan algoritma Decision Tree C4.5. Pemilihan algoritma ini dilatarbelakangi oleh kelebihan Decision Tree yang dapat mengelola data multi dimensi dan tingkat akurasi yang cukup tinggi. Selain itu, Decision Tree juga banyak digunakan pada kasus-kasus klasifikasi yang memerlukan pengambilan keputusan berbasis sistem induksi [7].

\section{METODOLOGI PENELITIAN}

\section{A. Data Mining}

Data mining merupakan kegiatan menganalisis dataset dalam jumlah besar untuk menemukan relasi yang tidak diketahui sebelumnya dan merangkum dalam bentuk data baru yang dapat dipahami dan bermanfaat bagi pemilik data. Berdasarkan tipe pekerjaannya, data mining dibagi menjadi 5, yaitu Exploratory Data Analysis (EDA), Descriptive Modeling, Predictive Modeling, Penemuan Pola dan Aturan, serta Pemanggilan Konten [8].

Secara umum, proses Knowledge Discovery from Data (KDD) merupakan proses sekuensial yang bersifat iteratif untuk menemukan pengetahuan baru dari data yang tersedia. Proses KDD ini memiliki 7 tahap dimulai dari proses data 
cleaning, integrasi data, pemilihan dataset yang relevan, proses transformasi data, data mining, evaluasi pola yang dihasilkan, serta presentasi pengetahuan. Secara singkat, proses KDD tersebut dapat dilihat pada Gambar 1 berikut:

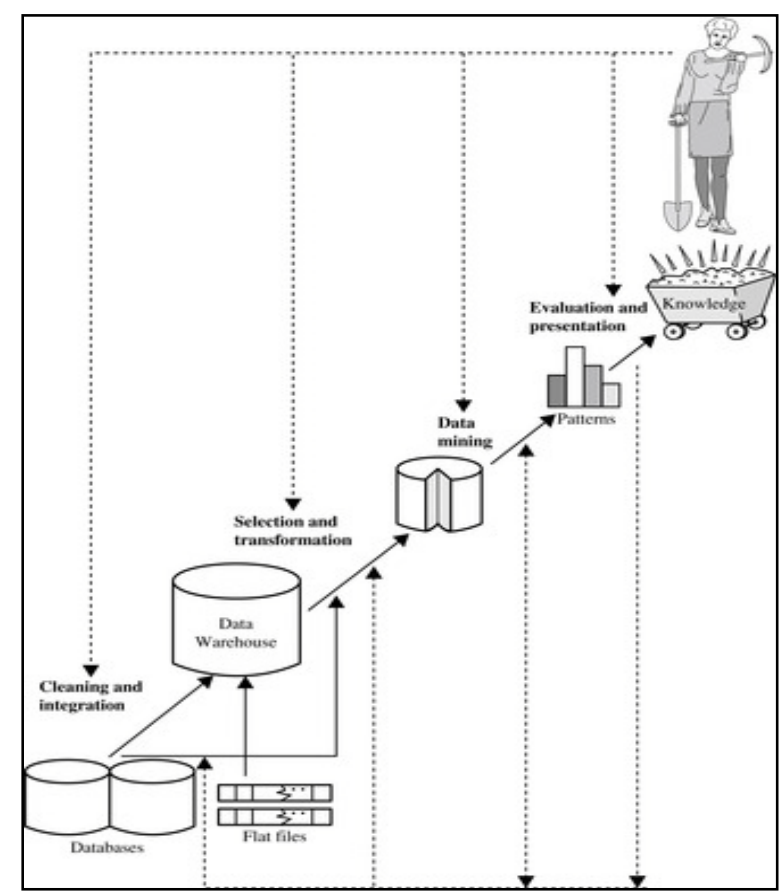

Gambar 1. Data Mining Sebagai Salah Satu Tahap Proses Penememuan Informasi (KDD).

\section{B. Decision Tree C4.5}

Klasifikasi merupakan proses penemuan model atau fungsi yang mendeskripsikan dan membedakan kelas data atau konsep untuk memprediksikan kelas atau objek dimana kelas data pada objek yang baru belum diketahui [7]. Pemodelan hasil klasifikasi direpresentasikan dalam berbagai bentuk, seperti classification rules, decision trees, mathematical formulae, atau neural networks. Dibanding metode data mining yang lain, klasifikasi dan decision tree merupakan bentuk representasi dasar yang banyak digunakan dalam berbagai metode machine learning [8].

Decision tree merupakan struktur mirip flowchart dimana masing-masing node mewakili nilai atribut dan masingmasing cabang merepresentasikan hasil pengujian, dan masing-masing daun merepresentasikan kelas atau distribusi kelas. Decision Tree C4.5 merupakan bentuk pengembangan dari algoritma ID3 yang mengadopsi pendekatan greedy dengan pengambilan keputusan berdasarkan tree yang terbentuk menggunakan pendekatan rekursif top down dan sistem bagi serang.

Algoritma Decision Treee C4.5 memiliki kelebihan dibanding ID3 dan CART karena kemampuannya untuk tidak membatasi cabang dalam bentuk biner. Selain itu, C4.5 secara default juga memisahkan cabang untuk masingmasing nilai ke dalam atribut kategori sehingga klasifikasi yang dihasilkan lebih terkelompokkan dibanding ekspektasi.

Decision tree memiliki tingkat akurasi yang cukup tinggi pada berbagai kasus. Penelitian yang dilakukan oleh
Harryanto dan Hansun menunjukkan tingkat akurasi sebesar $71 \%$ ketika diterapkan pada mekanisme rekrutmen pegawai baru [9]. Demikian juga saat diterapkan pada kasus prediksi oleh Rohman dan Supriyanto bahwa kelangsungan hidup penderita penyakit jantung, penggabungan Decision Tree C4.5 dengan Adaboost menghasilkan akurasi sebesar 92,24\% [10]. Pada penelitian Khotimah, Susanto dan Suciati penggabungan decision tree dan back propagation neural network dapat meningkatkan akurasi penerjemahan bahasa isyarat pada penderita tuna rungu dan wicara sebesar 96\% [11]. Berdasarkan kondisi tersebut dapat dilihat bahwa metode Decision Tree 4.5 merupakan metode yang dapat memberikan tingkat akurasi tinggi pada kasus-kasus prediktif dengan beberapa atribut kategori.

Secara umum, langkah-langkah pembentukan algoritma C4.5 adalah sebagai berikut:

- Langkah 1: tentukan atribut root node

- Langkah 2: tentukan cabang untuk masing-masing nilai atribut

- Langkah 3: pisahkan kasus sesuai cabang

- Langkah 4: Ulangi proses hingga semua kasus dalam cabang memiliki kelas yang sama

Untuk menentukan atribut yang menjadi root, dilakukan penghitungan nilai gain untuk masing-masing atribut menggunakan Rumus (1) berikut:

$\operatorname{Gain}\left(S_{x} A\right)=$ Entropy $(s)-\sum_{i=1}^{n} \frac{\left|S_{i}\right|}{|S|} *$ Entropy $\left(S_{i}\right)$

dimana:

$\left\{\mathrm{S}_{1}, \mathrm{~S}_{2}, \mathrm{~S}_{3}, \ldots, \mathrm{S}_{\mathrm{i}}, \ldots, \mathrm{S}_{\mathrm{n}}\right\}=$ partisi $\mathrm{S}$ sejumlah nilai atribut $\mathrm{A}$ $\mathrm{n}=$ jumlah atribut $\mathrm{A}$

$\| S_{i \mathbb{i}} \mid=$ jumlah kasus didalam partisi $S_{\mathrm{i}}$

$|S|=$ total kasus $\mathrm{S}$

Sementara untuk memperoleh nilai entropi digunakan Rumus (2) berikut.

Entropy $(s)=\sum_{i=1}^{n}-p_{i} * \log _{2} p_{i}$

dimana:

$\mathrm{S}=$ jumlah kasus

$\mathrm{n}=$ jumlah kasus dalam partisi $\mathrm{S}$

$\mathrm{p}_{\mathrm{i}}=$ proporsi $\mathrm{S}_{\mathrm{i}}$ terhadap $\mathrm{S}$

C. Angka Kecukupan Gizi Untuk Anak Usia Sekolah Dasar

Sesuai dengan visi Indonesia Sehat 2015 dan UndangUndang nomor 36 tahun 2009 tentang Kesehatan pasal 141 ayat 1 tentang upaya perbaikan gizi masyarakat untuk peningkatan mutu gizi perseorangan dan masyarakat, salah satu upaya yang dapat dilakukan untuk meningkatkan mutu gizi pada anak usia sekolah dasar adalah melalui sarapan [12].

Sarapan pagi bagi anak sekolah memiliki peran penting untuk memenuhi $25 \%$ kebutuhan energi harian. Oleh karena itu, pemenuhan gizi seimbang mutlak diperlukan untuk meningkatkan konsentrasi, mood yang lebih baik, serta meningkatkan daya serap, reaksi positif, serta daya ingat [13].

Untuk memenuhi kebutuhan gizi seimbang, anak-anak memerlukan makanan yang mengandung sumber karbohidrat, 
protein, serta, serta rendah lemak [14]. Selain itu, pemilihan menu yang sesuai juga mempengaruhi preferensi anak untuk mengkonsumsi sarapan. Penelitian dari Imbar, Vera, dan Walalangi, menunjukkan bahwa minat anak usia 7-12 tahun dalam mengkonsumsi makanan dipengaruhi oleh variasi penampilan, rasa yang familiar, tekstur makanan yang mudah dikunyah, serta aroma yang menggugah selera [15].

Angka kecukupan gizi merupakan angka yang menggambarkan kecukupan gizi berdasarkan asupan gizi orang yang sehat. Untuk mengetahui kecukupan gizi, berat badan, tinggi badan, usia, jenis kelamin, energi cadangan bagi anak dan remaja, serta peningkatan pengeluaran energi yang berasal dari asupan pangan memiliki pengaruh yang cukup signifikan.

Untuk menentukan status gizi seseorang, WHO telah menetapkan rumus perhitungan Basal Metabolic Rate (BMR) yang dapat dilihat pada Tabel 1 serta kebutuhan energi menurut aktivitas yang dikelompokkan sesuai usia individu pada Tabel 2 sebagai berikut [16].

Tabel 1. Perhitungan BMR berdasarkan Jenis Kelamin [16].

\begin{tabular}{|lrr}
\hline Kelompok Umur & \multicolumn{1}{c}{ Laki-Laki } & \multicolumn{1}{c}{ Perempuan } \\
\hline 0 $-\mathbf{3}$ tahun & $60,9 \mathrm{~B}-54$ & $61,0 \mathrm{~B}-51$ \\
\hline $\mathbf{3}-\mathbf{1 0}$ tahun & $22,7 \mathrm{~B}-495$ & $22,5 \mathrm{~B}+499$ \\
\hline $\mathbf{1 0}-\mathbf{1 8}$ tahun & $17,5 \mathrm{~B}+651$ & $12,2 \mathrm{~B}+746$ \\
\hline $\mathbf{1 8}-\mathbf{3 0}$ tahun & $15,3 \mathrm{~B}+679$ & $14,7 \mathrm{~B}+496$ \\
\hline $\mathbf{3 0}-\mathbf{6 0}$ tahun & $11,6 \mathrm{~B}+879$ & $8,7 \mathrm{~B}+829$ \\
\hline$\geq \mathbf{6 0}$ tahun & $13,5 \mathrm{~B}+487$ & $10,5 \mathrm{~B}+596$ \\
\hline
\end{tabular}

Keterangan: $\mathrm{B}=$ berat badan $(\mathrm{kg})$.

Tabel 2. Kebutuhan Energi Menurut Aktivitas [16].

\begin{tabular}{|llr}
\hline Aktivitas/Gender & \multicolumn{1}{c}{ Jenis Kegiatan } & \multicolumn{1}{c}{$\begin{array}{c}\text { Faktor } \\
\text { Aktivitas }\end{array}$} \\
\hline Sangat ringan & $\begin{array}{l}100 \% \text { waktu untuk } \\
\text { duduk/berdiri }\end{array}$ & 1,30 \\
\hline Ringan - Pria & $\begin{array}{l}75 \% \text { waktu untuk } \\
\text { duduk/berdiri }\end{array}$ & 1,56 \\
Sedang - Pria & $\begin{array}{l}\text { 25\% waktu untuk } \\
\text { berdiri/bergerak }\end{array}$ & 1,55 \\
Wanita & $\begin{array}{l}\text { duduk/berdiri } \\
\text { 40\% waktu untuk } \\
\text { aktivitas tertentu }\end{array}$ & 1,76 \\
\hline Berat - Pria & $\begin{array}{l}40 \% \text { waktu untuk } \\
\text { duduk/berdiri }\end{array}$ & 1,70 \\
Wanita & $\begin{array}{l}60 \% \text { waktu untuk } \\
\text { aktivitas tertentu }\end{array}$ & 2,10 \\
\hline
\end{tabular}

Berdasarkan hasil BMR dan kebutuhan energi menurut aktivitasnya, selanjutnya dilakukan perhitungan nilai berat badan ideal menggunakan rumus Body Mass Index (BMI) sesuai Persamaan 3 berikut:

$$
B M I=\frac{B B}{T B^{2}}
$$

dimana:

$\mathrm{BB}=$ berat badan $(\mathrm{kg})$

$\mathrm{TB}=$ tinggi badan $(\mathrm{m})$
Hasil perhitungan BMI tersebut berguna untuk menentukan batas ambang berat badan berdasarkan kategori. Batas ambang BMI ditentukan merujuk ketentuan FAO/WHO dengan modifikasi nilai ambang sesuai pengalaman klinis dan hasil penelitian di negara berkembang seperti yang dapat dilihat pada Tabel 3 berikut:

Tabel 3. Nilai Ambang BMI Untuk Anak Indonesia [1].

\begin{tabular}{rrr}
\multicolumn{1}{c}{ Usia (Tahun) } & \multicolumn{1}{l}{ Laki-Laki } & \multicolumn{1}{l}{ Perempuan } \\
\hline 6 & $13,7-17,0$ & $13,4-17,1$ \\
\hline 7 & $13,7-17,4$ & $13,4-17,6$ \\
\hline 8 & $13,8-18,0$ & $13,5-18,3$ \\
\hline 9 & $14,0-18,6$ & $13,7-19,1$ \\
\hline 10 & $14,2-19,4$ & $14,0-20,0$ \\
\hline 11 & $14,6-20,2$ & $14,4-20,9$ \\
\hline 12 & $15,0-21,0$ & $14,7-21,5$ \\
\hline
\end{tabular}

\section{HASIL DAN PEMBAHASAN}

A. Penghitungan Angka Kecukupan Gizi Menggunakan Decision Tree C4.5

Untuk mengetahui kondisi kecukupan gizi siswa dan untuk menentukan rekomendasi menu sarapan yang sesuai, dilakukan pemeriksaan fisik dan penyebaran kuesioner terhadap 360 siswa kelas 1 sampai dengan kelas 6 dengan menggunakan variabel kriteria: kelas, usia, berat badan $(\mathrm{kg})$, dan tinggi badan (meter). Berdasarkan data tersebut, selanjutnya dilakukan penghitungan BMR, faktor aktivitas, BMI, nilai ambang, dan kebutuhan energi saat sarapan. Hasil pengujian terhadap nilai ambang menghasilkan kesimpulan bahwa $79,7 \%$ siswa di SD XYZ memiliki nilai ambang kecukupan gizi normal, 12,5\% siswa mengalami kekurangan berat badan, dan $7,8 \%$ siswa mengalami kelebihan berat badan (Tabel 4).

Tabel 4. Persentase Nilai Ambang Siswa SD XYZ.

\begin{tabular}{llrrrr}
\hline & & & Valid & Cumulative \\
& & Freq. & Percent & Percent & Percent \\
\hline Valid & Kekurangan BB & 45 & 12,5 & 12,5 & 12,5 \\
\cline { 2 - 6 } & Normal & 287 & 79,7 & 79,7 & 92,2 \\
\cline { 2 - 6 } & Kelebihan BB & 28 & 7,8 & 7,8 & 100,0 \\
\cline { 2 - 6 } & Total & 360 & 100,0 & 100,0 & \\
\hline
\end{tabular}

Pengujian lebih lanjut menggunakan rumus Holliday Zegar Friedman dan Ray, berhasil mengidentifikasi kebutuhan kalori harian untuk masing-masing individu serta prosentasi kebutuhan karbohidrat, protein, lemak, dan serat sehingga menghasilkan nilai rata-rata yang dapat dilihat pada Tabel 5 sebagai berikut [17]: 
Tabel 5. Rata-Rata Kebutuhan Kalori dan Makronutrien Saat Sarapan [17].

\begin{tabular}{lrrrrr}
\hline & $\begin{array}{c}\text { Keb. } \\
\text { Kalori } \\
\text { Sarapan } \\
\text { (kkal) }\end{array}$ & $\begin{array}{c}\text { Karbohi } \\
\text { drat } \\
(\mathbf{4 5 \% )}\end{array}$ & $\begin{array}{c}\text { Protein } \\
(\mathbf{1 0 \% )}\end{array}$ & $\begin{array}{c}\text { Lemak } \\
(\mathbf{3 5 \% )}\end{array}$ & $\begin{array}{c}\text { Serat } \\
(\mathbf{1 0 \% )}\end{array}$ \\
\hline $\boldsymbol{N}$ Val & 360 & 360 & 360 & 360 & 360 \\
\cline { 2 - 7 } $\boldsymbol{M i s}$ & 0 & 0 & 0 & 0 & 0 \\
\hline Mean & 472,7250 & 212,7263 & 47,2725 & 165,4537 & 47,2725 \\
\hline Std. & 95,86358 & 43,13861 & 9,58636 & 33,55225 & 9,58636 \\
Dev. & & & & & \\
\hline Var. & 9189,827 & 1860,940 & 91,898 & 1125,754 & 91,898 \\
\hline
\end{tabular}

Ditinjau dari kebutuhan makronutrientnya, diketahui bahwa usia, jenis kelamin, berat badan, tinggi badan, BMR dan BMI mempengaruhi kebutuhan individu terhadap karbohidrat, demikian juga faktor yang sama mempengaruhi kebutuhan protein, lemak, maupun serat (Tabel 6).

Tabel 6. Hasil Perhitungan Gain Atribut BMI Terhadap Status Ambang Gizi.

\begin{tabular}{cc}
\hline Atribut & Gain \\
\hline BMI & 0.627 \\
\hline
\end{tabular}

Berdasarkan hasil korelasi yang diperoleh, selanjutnya dilakukan penghitungan entropi dan information gain terhadap atribut BMI untuk menghasilkan nilai gain pada Tabel 7 dan pola nilai ambang status gizi anak dalam bentuk tree pada Gambar 2.

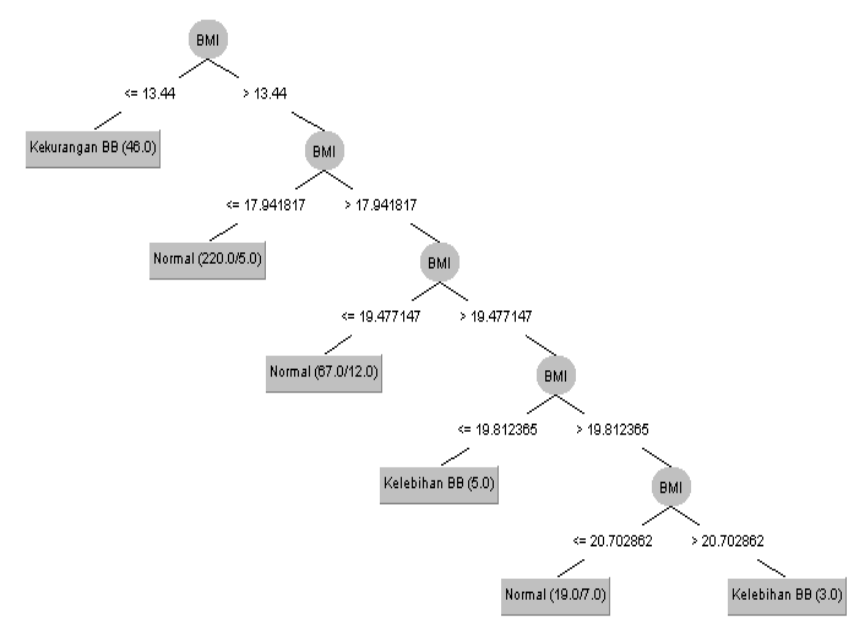

Gambar 2. Decision Tree BMI Terhadap Nilai Ambang Gizi Anak.

Tabel 7. Hasil Perhitungan Nilai Gain Masing-Masing Atribut Terhadap Kebutuhan Kalori Sarapan.

\begin{tabular}{ll}
\hline \multicolumn{1}{c}{ Atribut } & Gain \\
\hline Usia & 0.853 \\
\hline Berat Badan (kg) & 0.784 \\
\hline BMR & 0.768 \\
\hline Tinggi Badan (cm) & 0.657 \\
\hline BMI & 0.397 \\
\hline
\end{tabular}

Dari Gambar 2 dapat diketahui pola bahwa anak-anak yang memiliki BMI $\leq 13.44$ akan cenderung kekurangan berat badan, anak-anak dengan 13.44< BMI $\leq 19.47$ memiliki berat badan normal, dan anak-anak dengan BMI $>$ 19.47 akan cenderung kelebihan berat badan.

Berdasarkan hasil pengukuran status nilai ambang gizi, selanjutnya dilakukan analisis untuk mengetahui tren kebutuhan kalori saat sarapan. Hasil analisis terhadap 5 variabel kriteria menghasilkan nilai gain pada tabel 8 dan pola sebagaimana pada gambar 3 .

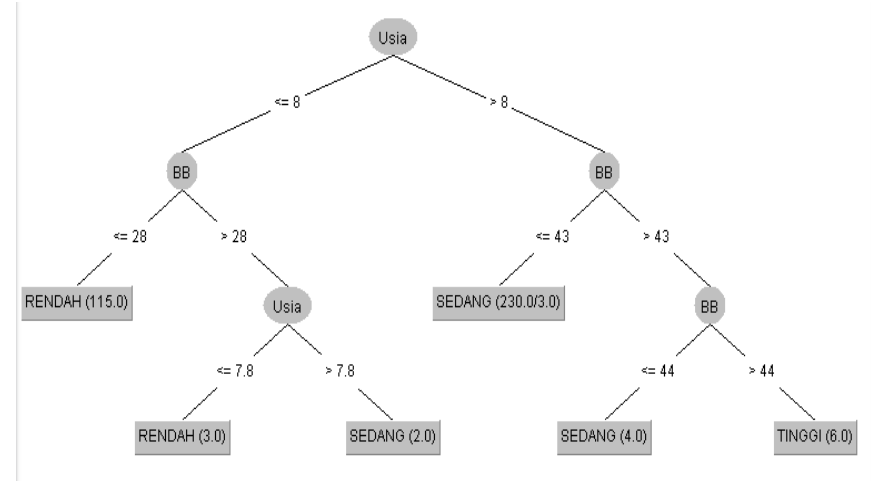

Gambar 3. Decision Tree C4.5 Kebutuhan Kalori Sarapan Untuk Anak Usia 7-12 Tahun.

Tabel 8. Kebutuhan Kalori Dalam kkal Untuk MasingMasing Kategori.

\begin{tabular}{lrr}
\hline Kategori & Kebutuhan Kalori (Dalam kkal) \\
\hline Rendah & $<384$ \\
\hline Sedang & $384-474$ \\
\hline Tinggi & $>474$ \\
\hline
\end{tabular}

Berdasarkan hasil responden, diketahui bahwa jumlah kalori yang dibutuhkan anak-anak pada sarapan dapat dibagi menjadi 3 kategori, yaitu: rendah, sedang, dan tinggi dengan ketentuan nilai kalori (dalam kkal) yang dapat dilihat pada Tabel 9 sebagai berikut:

Tabel 9. Hasil Perhitungan Nilai Gain Atribut Terhadap Kebutuhan Karbohidrat Pada Anak.

\begin{tabular}{lr}
\hline \multicolumn{2}{c}{ Atribut } \\
\hline Usia & 0.853 \\
\hline Berat Badan (kg) & 0.784 \\
\hline BMR & 0.768 \\
\hline Tinggi Badan (cm) & 0.657 \\
\hline BMI & 0.397 \\
\hline Jenis Kelamin & 0 \\
\hline
\end{tabular}

Berdasarkan Gambar 4 dapat diketahui bahwa anak-anak yang berusia $\leq 8$ tahun cenderung memiliki kebutuhan kalori rendah hingga sedang, sedangkan anak berusia $>8$ tahun memiliki kebutuhan kalori sedang hingga tinggi.

Analisis lebih dalam dilakukan untuk mengetahui jumlah kebutuhan makronutrien penyusun menu sarapan yang terdiri dari: karbohidrat, protein, lemak, dan serat. Pola yang dihasilkan penting bagi ahli gizi maupun orangtua untuk menyusun menu sarapan sehat sesuai kebutuhan gizi anak. 
Hasil perhitungan gain pada Tabel 9 menghasilkan informasi bahwa usia dan berat badan merupakan faktor penting yang mempengaruhi kebutuhan karbohidrat pada anak.

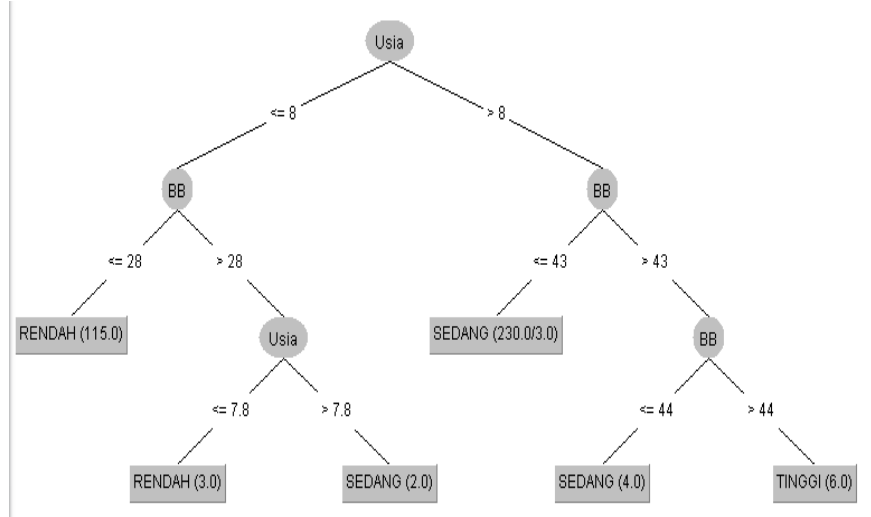

Gambar 4. Decision Tree C4.5 Kebutuhan Karbohidrat Untuk Anak Usia 7-12 Tahun.

Dari hasil decision tree pada Gambar 4, dapat dilihat bahwa secara umum anak usia $\leq 8$ tahun membutuhkan konsumsi karbohidrat dalam jumlah sedikit $(\leq 172$ gram/menu), dimana sebagian anak $7<$ usia $\leq 8$ tahun memerlukan karbohidrat dalam jumlah sedang (172.8 213.3 gram/menu). Konsumsi karbohidrat dalam jumlah besar ( $>213.3 \mathrm{gram} / \mathrm{menu})$ diperlukan sebagian anak berusia $>8$ tahun yang memiliki berat badan $>44 \mathrm{~kg}$, sedangkan selain itu memerlukan karbohidrat dalam jumlah sedang $(172.8-213.3 \mathrm{gram} / \mathrm{menu})$.

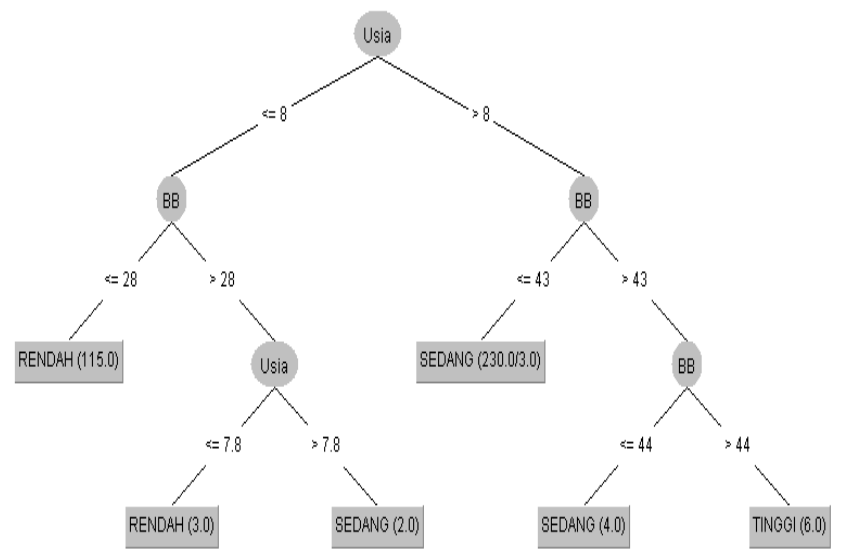

Gambar 5. Decision Tree Kebutuhan Protein Untuk Anak Usia 7-12 Tahun.

Hasil pengujian terhadap variabel protein menunjukkan nilai gain sama dengan yang ditunjukkan pada tabel 10 dimana usia dan berat badan menjadi faktor penentu kebutuhan konsumsi protein harian pada anak. Selanjutnya, struktur tabel decision tree pada Gambar 5 menunjukkan bahwa untuk anak usia $\leq 8$ tahun cenderung memerlukan protein dalam jumlah kecil $(<38.4$ gram/menu), meskipun sebagian anak usia 7-8 tahun menunjukkan tingkat kebutuhan protein dalam jumlah sedang (38.4 - 47.4 gram $/ \mathrm{menu})$. Sementara untuk anak usia $>8$ tahun dengan berat badan $\leq$ secara umum memerlukan protein dalam jumlah sedang (38.4 - 47.4 gram/menu), sedangkan anak usia $>8$ tahun dengan berat badan $>44 \mathrm{~kg}$ memerlukan protein dalam jumlah besar ( $>47.4$ gram $/ \mathrm{menu}$ ) untuk memenuhi $10 \%$ AKG.

Hasil konstruksi decision tree untuk mengetahui kebutuhan konsumsi lemak pada anak usia 7-12 tahun pada gambar 6 menunjukkan bahwa pada anak usia $\leq 8$ tahun dengan berat badan $\leq 28 \mathrm{~kg}$ cenderung memerlukan sedikit konsumsi lemak ( $\leq 134.4$ gram/menu), sedangkan anak dengan berat badan $>28 \mathrm{~kg}$ memerlukan konsumsi lemak dalam jumlah sedang (134.4 - 165.9 gram/menu). Untuk anak berusia $>8$ tahun, konsumsi lemak dalam jumlah tinggi diperlukan bagi anak-anak dengan berat badan $>44 \mathrm{~kg}$ (>165.9 gram $/ \mathrm{menu}$ ), sementara untuk anak dnegan berat badan $\leq 44 \mathrm{~kg}$ memerlukan lemak dalam jumlah sedang ( 134.4 - $165.9 \mathrm{gram} / \mathrm{menu}$ ).

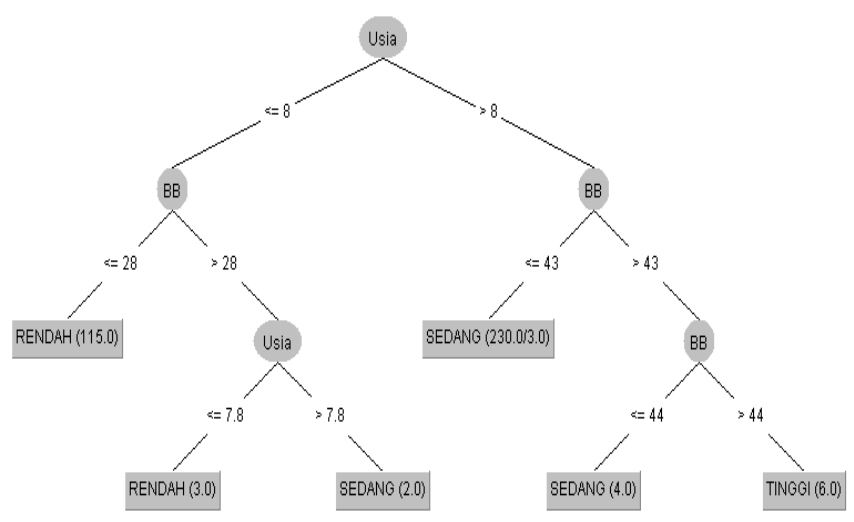

Gambar 6. Decision Tree Kebutuhan Konsumsi Lemak Pada Sarapan Anak Usia 7-12 Tahun.

Berbeda dari kebutuhan makronutrien lain yang ditentukan berdasarkan faktor usia dan berat badan, pemenuhan kebutuhan serat pada anak usia 7-12 tahun hanya ditentukan menggunakan variabel usia (Gambar 7), dimana anak usia $\leq 8$ tahun memerlukan konsumsi makanan rendah serat $(\leq 38.4$ gram $/$ menu $)$ dibanding anak usia $>8$ tahun (38.4 - 47.4 gram/menu). Kondisi ini juga menunjukkan bahwa nilai entropy variabel lain tidak memenuhi syarat untuk digunakan sebagai dasar pembuatan struktur tree.

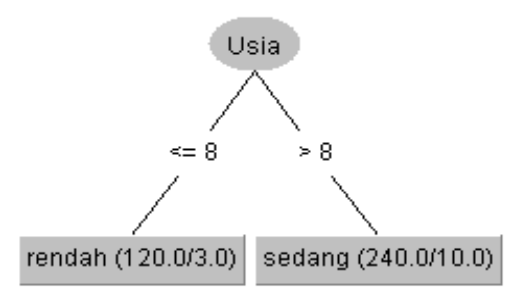

Gambar 7. Kebutuhan Serat Pada Anak Usia 7-12 Tahun. 


\section{KESIMPULAN}

Berdasarkan hasil analisis, dapat diketahui bahwa pada studi kasus penentuan kebutuhan gizi pada anak usia 7-12 tahun di sekolah XYZ dapat disimpulkan bahwa variabel BMI memiliki pengaruh yang signifikan untuk menentukan status ambang berat badan, kebutuhan energi sarapan, serta konsumsi makronutrien yang diperlukan anak usia 7-12 tahun. Selain itu, usia, berat badan, tinggi badan, BMR, dan BMI memiliki kontribusi pada penentuan kebutuhan energi pada anak, dan variabel jenis kelamin juga mempengaruhi pada proses penentuan kebutuhan konsumsi karbohidrat, protein, lemak, dan serat.

Untuk mencukupi 30\% dari kebutuhan kalori harian, anak berusia $\leq 8$ tahun dengan berat badan $\leq 28 \mathrm{~kg}$ dan sebagian anak dengan berat badan $>28 \mathrm{~kg}$ memerlukan asupan sebanyak $<384 \mathrm{kkal}$, sedangkan anak-anak usia $>8$ tahun dengan berat badan $\leq 43 \mathrm{~kg}$ dan anak usia $\leq 8$ tahun dengan berat badan $>28 \mathrm{~kg}$ memerlukan asupan kalori sebesar 384 - 474 kkal. Berdasarkan hasil penelitian di SD XYZ, konsumsi menu dengan kalori $>474$ kkal diperlukan hanya untuk anak usia $>8 \mathrm{~kg}$ yang memiliki berat badan $>$ $44 \mathrm{~kg}$.

Berdasarkan kebutuhan makronutrien yang diperlukan tubuh, dapat disimpulkan bahwa anak-anak usia 7-12 tahun hanya memerlukan makanan dengan kandungan karbohidrat, protein, lemak, dan serat rendah hingga sedang dengan besaran nutrisi per menu yang berbeda-beda untuk memenuhi kebutuhan $45 \%$ karbohidrat, $10 \%$ protein, $35 \%$ lemak, dan $10 \%$ serat dari AKG.

Hasil pengujian terhadap 360 siswa sekolah dasar kelas 1-6 menunjukkan bahwa penggunaan metode Decision Tree C4.5 mampu memberikan akurasi penilaian sebesar $82 \%$ dan dapat ditingkatkan melalui penggabungan dengan metode klasifikasi lain.

\section{REFERENSI}

[1] Direktorat Gizi Masyarakat Direktorat Jenderal Kesehatan Masyarakat Kementrian Kesehatan. (2018). Buku Saku Pemantauan Status Gizi Tahun 2017. Diakses dari http://www.kesmas.kemkes.go.id/assets/ upload/dir_519d41d8cd98f00/files/Buku-Saku-HasilPSG-2016_842.pdf.

[2] Elisa, P.A. (2012). Determinan Status Gizi Pada Siswa Sekolah Dasar. Jurnal Kesehatan Masyarakat, 7(2), pp. 122-126. ISSN 1858-1196.

[3] Lestari, I.D., Ernalia, Y. \& Restuastuti, T. (2016). Gambaran Status Gizi Pada Siswa Sekolah Dasar Kecamatan Bangko Kabupaten Rokan Hilir. Jurnal Online Mahasiswa Fakultas Kedokteran (JOM FK), 3(2).

[4] Jahri, I.W. \& Suyanto, Y.E. (2016). Gambaran Status Gizi pada Siswa Sekolah Dasar Kecamatan Siak Kecil Kabupaten Bengkalis. Jurnal Online Mahasiswa Fakultas Kedokteran (JOM FK).

[5] Riskesdas. (2014). Pedoman Gizi Seimbang. Kementrian Kesehatan Republik Indonesia.
[6] Perdana, F. \& Hardinsyah. (2013). Analisis Jenis, Jumlah, Dan Mutu Gizi Konsumsi Sarapan Anak Indonesia. Jurnal Gizi Dan Pangan, 8(1), pp. 39-46.

[7] Han, J., Pei, J., \& Kamber, M. (2011). Data Mining: Concepts and Techniques. Elsevier Science. Diakses dari:https://books.google.co.id/books?id=pQws07tdpjo C.

[8] Witten, I.H., Frank, E., \& Hall, M.A. (2011). Output: Knowledge Representation. In Data Mining: Practical Machine Learning Tools and Techniques, pp. 61-83. Diakses dari: https://doi.org/10.1016/B978-0-12374856-0.00003-1

[9] Harryanto, F.F., \& Hansun, S. (2017). Penerapan Algoritma C4.5 Untuk Memprediksi Penerimaan Calon Pegawai Baru di PT WISE. Jatisi, 3(2), pp. 95-103.

[10] Rohman, A., Suhartono, V., \& Supriyanto, C. (2017). Penerapan Algoritma C4.5 Berbasis Adaboost Untuk Prediksi Penyakit Jantung. Jurnal Teknologi Informasi, 13(1), pp. 13-19. Diakses dari: http://research.pps. dinus.ac.id/ index.php/Cyberku/article/view/4.

[11] Khotimah, W.N., Susanto, Y.A., \& Suciati, N. (2017). Combining Decision Tree and Back Propagation Genetic Algorithm Neural Network for Recognizing Word Gestures in Indonesian Sign Language Using Kinect. Journal of Theoretical and Applied Information Technology, Vol. 95, No. 2, pp. 292-298.

[12] Undang-Undang Republik Indonesia Nomor 36 Tahun 2009 tentang Kesehatan. Full-Text (2009).

[13] Ho, C., Huang, Y., If, Y.T.D., Lo, C., \& Wahlqvist, M. L. (2015). Research in Developmental Disabilities Breakfast is Associated With the Metabolic Syndrome and School Performance Among Taiwanese Children. Research in Developmental Disabilities, Vol. 43-44, pp. 179-188. Diakses dari: https://doi.org/10.1016/ j.ridd.2015.07.003.

[14] Al-Oboudi, L.M. et.al. (2010). Impact of Breakfast Eating Pattern on Nutritional Status, Glucose Level, Iron Status in Blood and Test Grades Among Upper Primary School Girls in Riyadh City, Saudi Arabia. Pakistan Journal of Nutrition, 9(2), pp.106-111.

[15] Imbar, H., Vera, T., \& Walalangi, R. (2016). Analisis Organoleptik Beberapa Menu Breakfast Kebutuhan Gizi Siswa Sekolah Dasar. Analisis Organoleptik, 8(1).

[16] Hardinsyah, Riyadi, H., \& Napitupulu, V. (2012). Kecukupan Energi, Protein, Lemak dan Karbohidrat. Departemen Gizi FK UI, 2004 (Wnpg 2004), pp. 1-26.

[17] Friedman, A. L., \& Ray, P. E. (2007). Maintenance Fluid Therapy: What It Is and What It Is Not. Pediatric Nephrology, 23, pp. 677-680. 